\title{
TREN PEMIKIRAN INTELEKTUAL MUSLIM KONTEMPORER DI TIMUR TENGAH PASCA-DIFITISME 1967
}

\author{
Yoyo \\ Minat Studi Kajian Timur Tengah \\ Program Studi Agama dan Lintas Budaya Sekolah Pascasarjana Universitas Gadjah Mada \\ Email: yoyo_ktt@ugm.ac.id dan yoyo_trainer@yahoo.com \\ Heddy Shri Ahimsa Putra dan Fadlil Munawar Manshur \\ Fakultas Ilmu Budaya Universitas Gadjah Mada \\ Siti Muti'ah Setiawati \\ Fakultas Ilmu Sosial dan Ilmu Politik Universitas Gadjah Mada
}

\begin{abstract}
This article is an effort to make a clear map on contemporary Muslim intellectuals in the Middle East after the Arab defeat in 1967. The Six-Day War took place in June 1967 was a disaster for the Arab world. It ended the ideology of Pan-Arab nationalism and encouraged the rise of four compating self-criticism ideologies: Marxism, Liberalism, Fundamentalism and Nationalism. The four ideologies have their own particular responses and solutions to the Arab crisis. The result of this research shows that Islamic fundamentalism is still the strongest ideology compared to the secular ideologies. The Arab Spring in 2011 proved the fact and paved a way for the Islmists to become dominant in the political arena, as recently shown in Egypt. The other Islamist militant groups, such as Jama'ah Islamiyyah are now more free to promote the implementation of Islamic syari'ah.
\end{abstract}

Keywords: Muslim intellectuals, the Arab defeat, and self-criticism ideologies.

\begin{abstract}
ABSTRAK
Artikel ini merupakan sebuah upaya membuat peta yang cukup jelas mengenai tren intelektual Muslim di Timur Tengah pasca difitisme Arab 1967. Perang Enam-Hari yang terjadi pada Juni 1967 merupakan derita bagi dunia Arab. Ia mengindikasikan berakhirnya ideologi Pan-Arabisme dan telah memicu lahirnya empat ideologi kritik-diri yang saling berkompetisi: Marxisme, Liberalisme, Fundamentalisme dan Nasionalisme dalam bentuk ekstrimnya. Keempat ideologi tersebut mempunyai respon dan tawaran solusi tersendiri terhadap krisis Arab. Di akhir penelitian ini memperlihatkan bahwa fundamentalisme Islam masih menjadi ideologi yang sangat kuat dibanding dengan ideologi-ideologi sekuler lainnya. Pasca the Arab Spring, fundamentalisme Islam di Mesir berhasil menjadi penguasa di samping semakin menguatnya gerakan-gerakan Islam lain di panggung politik. Kelompok-kelompok Islam militan pun semisal Jama'ah Islamiyyah menjadi semakin bebas dalam menyuarakan tuntutan penerapan syari'at Islam.
\end{abstract}

Kata Kunci: Intelektual Muslim, Difitisme Arab, dan Ideologi-ideologi Kritik-Diri. 


\section{PENGANTAR}

Studi mengenai intelektual di dunia Islam dan Timur Tengah pada khususnya, berdasarkan pengamatan Singer dan Gershoni (2008: 383) bahwa kajian ini “... [it] has not been a fashionable field in Middle Eastern studies...since the mid-1970s it has been pushed to the sidelines." Lebih tegas lagi, menurut Ibrahim M Abu-Rabi'(2004: 7) “the field of contemporary Arab [Muslim] thought is still virgin." Bidang kajian Islam yang masih jarang disentuh. Di Indonesia pun, kajian terhadap dinamika sosial intelektual Muslim merupakan kajian masih minim dilakukan dan bahkan sedikit "ditelantarkan" (Rumadi, 2008:7). Alasan yang paling mudah diterima karena "the importance of the intellectual in society and in the processes of modernization is generally marginal" (Hatina, 2007:8). Marginalisasi ini terjadi karena pemikiran intelektual seringkali dianggap terlalu idealis di tengah-tengah masyarakat yang cenderung bergerak ke arah pragmatis.

Melengkapi diskusi di atas, artikel ini berusaha menjabarkan peta sederhana tren pemikiran intelektual Muslim kontemporer di Timur Tengah khususnya pascakekalahan perang Arab-Israel pada 1967 atau kemudian dikenal dengan sebutan difitisme 1967 sampai tahun 2000-an. Difitisme 1967 telah banyak melahirkan gerakan ideologis, baik ke arah sekuler maupun Islamis sebagai respon dan jawaban atas persoalan-persoalan kemunduran yang terjadi di dunia Arab. Baru-baru ini, pasca-the Arab Spring semakin mengokohkan fakta bahwa pertarungan ideologis itu memang terbukti adanya.

Upaya untuk memetakan tren pemikiran intelektual Arab, tulisan ini pun diharapkan mampu memberikan jawaban terhadap persoalan-persoalan kontemporer seperti mengapa fundamentalisme agama di Timur Tengah masih menjadi satu-satunya tren ideologi yang mampu bertahan (dengan segala konsekuensinya), sedangkan ideologiideologi sekuler seperti liberalisme dan Marxisme semakin terpinggirkan dan tidak terlalu banyak diminati.

Buku Albert Hourani, Arabic Thought in the Liberal Age, 1798-1939 terbit pertama kali pada 1962 merupakan buku yang sangat terkenal dan buku pertama yang berbicara mengenai sejarah dan pergumulan pemikiran intelektual Arab dihadapkan pada isu modernitas yang dibawa oleh Barat. Dalam bukunya tersebut, Hourani menyebutkan empat generasi intelektual sekaligus sebagai representasi dari tren pemikiran Arab modern ke dalam empat periode, yaitu pertama, generasi antara tahun 1830-1870 Masehi dicirikan dengan tren "mengadopsi" lembaga hukum dan politik Barat demi kemajuan negara; Kedua, generasi antara tahun 1870-1900 Masehi ditandai dengan gerakan re-interpretasi Islam; Ketiga, generasi antara tahun 1900-1939 Masehi ditandai dengan menguatnya gerakan fundamentalisme sekaligus liberalisme Islam; dan Keempat, generasi pasca-Perang Dunia II sebagai tren nasionalisme Arab.

Abdallah Laroui, intelektual Arab asal Maghrib dalam bukunnya The Crisis of Arab Intellectuals bahwa empat periode sejarah pemikiran intelektual Arab dengan menambahkan periode 1967 ke atas sebagai era baru kebangkitan intelektual Arab, yaitu pertama, Nahdah - periode renaissance kultural Arab terbesar-, diawali pada abad ke-19 (1850 Masehi sampai tahun 1914 Masehi); Kedua, periode di antara dua Perang Dunia (PD I dan PD II) sampai pada pertengahan tahun 1950-an, ditandai oleh perkembangan pemikiran yang memainkan peranan utama dalamsetiapgerakansosialutamanyagerakan nasionalis; Ketiga, periode masa percobaan nasionalisme Arab di bawah payung ideologi persatuan Nasser dan Partai Ba'ath setelah PD II sampai pada Perang Arab-Israel 1967; dan Keempat, periode krisis moral juga politik pasca kekalahan Perang 1967 (hazimah) yang kemudian disebut sebagai the Second Nahdah merupakan Kebangkitan Intelektual Arab Kedua (Laroui, 1967: vii-viii).

Sementara Sharabi (1992: 94) memetakan empat fase tren pemikiran di dunia Arab 
mulai dari tahun 1880-1980 Masehi sebagai berikut, yaitu pertama, fase Turki Ustmani (1880-1918 Masehi), didominasi oleh ideologi reformisme dan sekularisme; Kedua, fase penjajahan Eropa (1918-1945 Masehi), didominasi oleh ideologi nasionalisme Arab, revivalisme Islam, dan Sosialismeliberal; Ketiga, fase kemerdekaan (19451980 Masehi), didominasi oleh ideologi sosialisme revolusioner, liberalism, dan fundamentalisme; dan keempat, fase pascakemerdekaan (1980 Masehi) sampai sekarang dengan ditandai oleh tren fundamentalisme Islam dan Kritisisme-Sekuler.

Sedikit berbeda dari periodesasi di atas, Halim Barakat (2012) memetakan pemikiran Arab ke dalam tiga periode, Pertama, fase formatif mulai dari tahun 1850-an hingga Perang Dunia I. Periode ini ditandai kecenderungan religius, yaitu benturan antara kelompok tradisional versus reformis; kecenderungan liberal dan radikal progresif; Kedua, fase meraih Perjuangan Nasional (1918-1945); dan Ketiga fase kemerdekaan dan pasca-kemerdekaan (1945-1992) yang ditandai dengan menguatnya gerakan liberalisme, fundamentalisme agama, dan Islam progresif. Berbeda dari penelitian di atas, artikel ini secara khusus akan melihat peta perkembangan intelektual Muslim kontemporer khususnya pasca-difitisme 1967 sampai sekarang.

Diakui oleh para sarjana Barat bahwa sulit untuk merumuskan definisi yang tepat tentang intelektual atau intellectuals. Salah satu alasannya karena seringkali definisi tersebut merupakan self-definitions (Bauman, 1987: 8), kurang objektif dan cenderung bias, definisi disusun atas dasar binary opposition antara siapa yang disebut "intellectuals" dan "non-intellectuals" dengan batas-batas yang sudah sangat jelas dikonstruksi oleh kelompok sosial tertentu.

Apabila merujuk pada makna dasar penggunaannya, Raymond (1985: 169-171), dalam Keywords: A vocabulary of culture and society menyebutkan bahwa kata "intellectual" digunakan untuk merujuk pada jenis orang tertentu atau seseorang yang melakukan pekerjaan tertentu. Kata ini efektif digunakan pada akhir abad ke19. Meskipun penggunaan kata itu sendiri kurang disukai, kata "intellectual" menjadi sangat popular dalam literature Inggris pada pertengahan abad ke-20. Kata "intelektual" sekarang digunakan secara netral untuk menggambarkan orang yang melakukan jenis pekerjaan tertentu dan utamanya jenisjenis pekerjaan yang bersifat umum.

Dalam tradisi Islam terdapat istilah klasik yang lazim digunakan untuk merujuk kepada sekelompok orang yang berkecimpung dalam tradisi keilmuan, istilah tersebut yaitu 'ulama (bentuk jamak dari 'álim) berarti sarjana atau scholar, orangorang yang memiliki pengetahuan (ilm). Akan tetapi, istilah ini digunakan hanya bagi "mereka yang memiliki pengetahuan agama" (Milson, 1972: 17). 'Ulama sebagai special groupe dalam masyarakat Muslim, cenderung lebih berperan sebagai moral caretakers dibanding sebagai pengkritik (Esposito, 2001: 14). Puncak kemapanan 'ulama dalam sejarah Islam klasik tercatat pada masa Dinasti Ustmani terdapat kerjasama harmonis antara 'ulama dan penguasa di mana ulama berperan sebagai pemegang legitimasi bagi kekuasaan raja (1972: 21; 2001: 14-16) atau disebut oleh Abdo (2000: 43) sebagai religious stamp of approval. Kekuasaan seorang raja tidak akan legitimate kalau belum mendapat persetujuan dari 'ulama. Merujuk pada deskripsi ini, istilah intelektual kurang tepat apabila dipadankan dengan kata 'ulama dalam tradisi Islam klasik.

Untuk konteks modern, tepatnnya pada akhir abad ke-19 terdapat dua kata Arab yang lazim digunakan sebagai padanan kata "intelektual": yaitu mutsaqqaf dan mufakkir, yang pertama berasal dari kata tsaqafa, kebudayaan (a man of culture) atau academically trained, ditempuh melalui jenjang pendidikan formal. Sedangkan yang terakhir berasal dari kata fikr atau thought (a man of thought). Dari dua istilah tersebut, penulis seperti halnya Hofmann (2007: 67) merasa lebih tepat untuk menggunakan kata mufakkir 
sebagai padanan untuk kata "intelektual" yang diartikan sebagai "analytical mind who communicate," menandakan bahwa proses menjadi intelektual tidak mesti melalui sebuah tahapan pendidikan formal yang tinggi, melainkan melalui sebuah proses pemikiran yang aktif dan produktif. Lebih dari itu, seorang intelektual (al-mufakkir) adalah "someone whose place it is publicly to raise embarrassing questions, to confront orthodoxy and dogmas" (Said, 1994). Tugasnya adalah menyampaikan pemikiran dengan tujuan untuk melakukan perubahan meskipun gagasan tersebut boleh jadi sangat bertentangan dengan gagasan yang lazim berlaku.

\section{PEMBAHASAN \\ Difitisme 1967}

Tanggal 5 Juni 1967 Masehi, Israel menyerang dan menghancurkan angkatan udara Mesir. Beberapa hari kemudian, Israel menduduki Sinai juga Suez, Yerusalem serta Palestina bagian Yordania, dan Syria bagian selatan (Dataran Tinggi Golan) (Hourani, 1992: 413). Kekalahan 1967 Masehi ini dipandang oleh para pemikir Arab-Muslim bukan hanya sekedar kekalahan teknologi, melainkan juga kekalahan moral. Apabila bangsa Arab dapat dikalahkan dengan begitu cepat, pasti ada yang salah dengan sistem moralnya. Permasalahan yang lebih penting adalah tentang identitas bangsa Arab dihubungkan dengan warisan masa lampau (turāst) dan tantangan zaman. Haruskah mereka mengambil nilai-nilai dari luar, ataukah dapat digali dari kultur dan nilai-nilai yang telah diwariskan [ArabIslam] untuk sampai pada dunia modern? Pertanyaan ini memperlihatkan relasi antara identitas Arab-Muslim dan pada ketergantungan pada dunia Barat (1992: 442443).

Pertama kalinya pasca 1967, utamanya tahun 1970 dan 1980-an, terdengar istilah Islamis atau fundamentalis (al-ushuliyyah), dan istilah self-criticism atau Marxist selfcriticism. Hal ini merupakan akibat dari kekalahan perang Arab tersebut dan juga mengindikasikan adanya kematangan dalam ranah pemikiran intelektual Arab pada era 1970 dan 1980-an (Abu-Rabi', 2004: 10). Kalau pada era Kebangkitan Arab Pertama pertanyaan yang muncul adalah "mengapa kita (bangsa Arab-Muslim) mengalami kemunduran sementara yang lain (Barat-Kristen) mengalami kemajuan?" maka pertanyaan yang muncul di kalangan intelektual Arab era Kebangkitan Kedua adalah "mengapa kita (Arab-Muslim, Dunia Ketiga) gagal merealisasikan kebangkitan kita? (Al-Jabiri, 1990: 131).

Dengan mewaspadai akan bangkitnya gerakan tradisionalisme (dalam bentuk fundamentalisme Islam utamanya) dalam pemikiran Arab kontemporer, Laroui pada saat yang sama optimis bahwa telah lahir gerakan intelektual baru dalam menghadapi krisis difitisme 1967 yang disebutnya sebagai the second Nahdah (Laroui, 1976: 67). Hal ini berarti bahwa pemikiran Arab sedang menghadapi era Kebangkitan Kedua seperti halnya Kebangkitan Pertama pada abad ke-19 Masehi. Menurutnya Laroui bahwa Kebangkitan Arab Kedua (the second Nahdah) ini sebenarnya telah diawali pada tahun 19631965 Masehi yang disebut dengan era Nasser dan berkembang menjadi sangat matang sejak tahun 1970-an sampai sekarang setelah masa percobaan Nasserisme menemui kegagalan ( Laroui, 1976: 92-93).

\section{Intelektual Maghrib}

Meskipun kekalahan perang ArabIsrael 1967 ini lebih dirasakan oleh intelektual Masyriq (Arab-Timur) seperti Mesir utamanya, Syria, dan juga Libanon, tetapi refleksi atas kekalahan tersebut ikut diramaikan oleh intelektual Arab dari wilayah Maghrib seperti Maroko dan Aljazair (Browers, 2009: 21). Refleksi tersebut juga menandai lahirnya tren baru intelektual Arab kontemporer dari Maghrib. Sharabi (1988) mencatat bahwa gerakan yang muncul di Maghrib ini menerima gagasan filsafat dan epistemologi baru dari Barat, utamanya Perancis. Intelektual Maghrib 
kontemporer seperti Muhammad Arkoun dari Aljazair dan Muhammad Abid alJabiri dari Maroko merupakan representasi dari intelektual tersebut. Mereka berupaya menggunakan metode strukturalis baru, yaitu post-strukturalis dan dekonstruksi untuk menafsirkan kembali teks-teks klasik warisan Arab-Islam.

Maghrib menjadi posisi yang sangat penting dalam hal menerima gerakan atau tren intelektual dan kultural dari Timur dan Mesir utamanya sejak era pertama Nahdah. Akan tetapi, posisi sebagai penerima ini (receiver) mulai bergeser dan berubah menjadi producer bahkan sender pemikiran-pemikiran yang tak kalah hebatnya dari Masyriq, maka otomatis Masyriq mulai menerima dan mengakui produk baru pemikiran progressif ini. Perubahan posisi demikian dimulai pada pertengahan tahun 1980-an dan ada satu alasan penting sebagai latar belakangnya yaitu adanya expansion of change pemikiran antara Masyriq dan Maghrib (Nagawasa, 1992). Contoh ini bisa dilihat dalam sebuah buku dengan judulnya yang mencerminkan adanya kekuatan intelektual baru dari Maghrib yaitu Hiwār al-Masyriq wal Maghrib (Dialog Timur dan Barat), sebuah dialog antara pemikir terkenal asal Timur (Mesir), yaitu Hasan Hanafi dengan Muhammad Abid al-Jabiri sebagai representasi intelektual Arab kontemporer dari Barat (Maroko).

Wacana keseimbangan antara intelektual Masyriq dan Maghrib di atas didukung oleh tiga faktor utama, yaitu pertama, majalah intelektual yang dipublikasikan di Masyriq mulai terhubung dengan produk-produk pemikiran intelektual Maghrib; Kedua, adanya aktivitas institusi dan organisasi inter-Arab dalam mengorganisir simposium dan konferensi ilmiah; Ketiga, adanya peranan 'gates of Paris.' Hasan Hanafi, Muhammad Abid al-Jabiri, dan juga Arkoun merupakan representasi produk ketiga ini (Nagawasa, 1992: 98). Produk dari 'gates of Paris' sebagian besar intelektual Maghrib dan sedikit dari Masyriq semisal Hasan Hanafi lebih senang menulis karya-karyanya dalam bahasa Perancis, seperti yang dilakukan oleh
Muhammad Arkoun dan Abdallah Laroui. Hal demikian tentunya menjadi kendala linguistik tersendiri bagi sebagian besar audiens Muslim yang secara umum hanya mahir bahasa Arab atau Inggris (Abu-Rabi, 2004: 44-45).

\section{Tema-Tema Pemikiran}

Meskipun beberapa tulisan telah dihasilkan selama abad ke-20 ini dan bahkan telah dimulai pada abad ke-19 Masehi (era Kebangkitan Arab Pertama) yang jumlahnya lebih terbatas, tetapi tulisantulisan yang dihasilkan pada tahun 1960, 1970, dan 1980-an jauh lebih penting dan sangat tajam. Tulisan-tulisan itu memiliki nada menyedihkan tentang mereka dan menunjukkan adanya keinginan besar untuk bergulat dengan problem modernitas. Tulisan-tulisan tersebut dimaksudkan untuk proses perubahan, sekalipun terlalu abstrak atau idealistik (Boullata, 2002: 3).

Karya-karya tersebut sebagian sangat terinspirasi oleh tiga tren utama aliran pemikiran Barat, yaitu kritisisme AngloAmerika, Marxisme Barat, dan pemikiran strukturalis dan post-strukturalis Perancis (Sharabi, 1992: 104). Tahun 1967 Masehi sekaligus memberi sinyal curahan sejumlah tulisan-tulisan Arab kritis tentang situasi Arab, mulai dari nuansa filsafat, agama, dan sastra. Banyak pemikir Arab pasca 1967 dipaksa untuk memikirkan ulang sejumlah isu besar yang selama ini sudah taken for granted bahkan sampai pada tahap sakralisasi teks (Abu-Rabi', 2004: 59).

Persoalan yang diangkat oleh intelektual Arab kontemporer sangat banyak dan beberapa tema masih terkait dengan pemikiran yang dihasilkan pada era Kebangkitan Arab Pertama. Masing-masing intelektual mempunyai kecenderungan dan fokus masing-masing dalam melihat satu permasalahan. Oleh karena itu, tema yang satu boleh jadi dibahas lebih detail dibandingkan dengan tema yang lain.

Tema-tema tersebut di atas misalnya, posisi perempuan dalam masyarakat Arab, pada umumnya memperoleh ruang 
pembahasan yang lebih besar dibanding sistem pendidikan di dunia Arab. Kedudukan Islam dalam masyarakat Arab mendapat perhatian yang lebih besar dibanding persoalan-persoalan kemanusiaan dan hakhak asasi individual. Persoalan politik, khususnya yang terkait dengan kebijakan asing lebih sering menjadi acuan terhadap persoalan-persoalan ekonomi. Gagasan tentang sosialisme dan nasionalisme di dunia Arab lebih menarik banyak kajian dibanding dengan gagasan tentang kebebasan dan demokrasi. Imperialisme Barat dan zionisme sebagai penghambat kemajuan Arab, dianalisis secara lebih mendalam daripada persoalan sistem kelas dalam masyarakat Arab (Boullata, 2002: 7).

Dari tema-tema tersebut $\mathrm{di}$ atas, persoalan mengenai bagaimana Islam diposisikan dalam ranah kehidupan sosial-politik tetap merupakan isu utama intelektual kedua generasi (Kebangkitan Arab Pertama dan Kedua). Hal ini menjadi indikator penting bahwa posisi dan peranan Islam dalam konteks sosial politik akan tetap menjadi isu utama baik bagi mereka yang memiliki kecenderungan ke arah Liberal, Marxis, maupun Islamis atau fundamentalis tentunya dengan porsi yang berbeda-beda.

\section{Gerakan Self Criticism}

Secara sederhana, Kebangkitan Arab Kedua dengan berbagai bentuk ideologisnya dapat disebut sebagai gerakan "Kritik Diri" atau SelfCriticism. Yaitu satu kesadaran kritis terhadap kondisi yang sedang dihadapi bangsa Arab sebagai konsekuensi dari perasaan dan refleksi atas difitisme 1967. Menurut Fouad Ajami (1981: 32-87), Issa J. Boullata (2002: 4-5; 1988: 150-153 ), Sharabi (1988: 92-94), Abu-Rabi' (2004: 63-92), dan Dessouki (1973: 187-195), gerakan self criticism tersebut dapat dikelompokkan ke dalam empat klasifikasi utama.

Pertama, sekelompok intelektual yang menginginkan perubahan masyarakat Arab secara fundamental. Pandangan agama harus dihilangkan dan diganti oleh pemikiran sekuler yang berpijak pada rasionalisme, ilmu pengetahuan, dan ekonomi sosialis. Kelompok ini diwakili oleh kalangan Marxis (Marxist criticism) atau disebut pula sebagai gerakan kritisisme radikal.

Kedua, sekelompok lebih besar intelektual Arab yang menilai kebudayaan Arab tradisional (turāst) masih sesuai di era modern hanya jika diinterpretasikan dan dipahami secara lebih baik, dan hanya jika bagian elemen-elemen tertentu dikembangkan dengan melihat kebutuhankebutuhan modern dan atas dasar pengalaman dari negara-negara modern (Barat). Kelompok ini diwakili oleh kalangan liberal atau liberal criticism.

Ketiga, kelompok intelektual yang lebih memperhatikan pada aspek-aspek agama. Mereka melihat elemen-elemen Islam dalam kebudayaan Arab sebagai elemen prinsipil. Kelompok ini diwakili oleh kalangan fundamentalis atau fundamentalist criticism. Terakhir, kelompok intelektual pragmatis dalam melihat peranan agama dan lebih menonjolkan rasa persatuan nasional. Tren ini disebut sebagai nationalist criticism.

Empat, kecenderungan umum tersebut di atas terkadang tidak memiliki batasbatas yang pasti, karena ada intelektual yang masuk salah satu tren sejauh berkaitan dengan persoalan tertentu, sementara dalam masalah-masalah lainnya dia lebih tepat dimasukkan dalam tren yang lain. Beberapa intelektual secara jelas dan sadar beralih dari satu tren ke tren lainnya dalam waktu-waktu tertentu karena kehidupan personalnya atau seiring dengan perkembangan sosial politik (Boullata, 2002: 6), fenomena ini disebut oleh Abu-Rabi' (2004) sebagai intellectual conversions.

Pada level linguistik, gerakan kritisisme bertujuan untuk melakukan transformasi kosakata dengan menciptakan terminologiterminologi baru. Pada level interpretatif, berupaya membongkar kategori-kategori tafsir dominan dan membangun tafsir yang lebih fresh. Sedangkan pada level ideologis berupaya mendekonstruksi pemikiran ideologi dalam berbagai bentuknya dan membuka "ruang" dialog. Terakhir, pada 
level praktis, mencoba melakukan delegitimasi tonggak teoritis otoritas teologis dan kekuasaan politis (Sharabi, 1992: 105). Kecenderungan seperti ini hanya akan terlihat pada kelompok Marxis/Kiri, dan kelompok liberal. Sedangkan yang kedua terakhir yaitu nasionalis dan fundamentalis cenderung eksklusif dan lebih senang untuk melakukan mobilisasi massa daripada menghasilkan pemikiran kreatif dan reflektif.

\section{Kritisisme Marxis/Kiri}

BagikelompokMarxis/KiriArab, tragedi 1967 bukan hanya akibat dari praktek korupsi dan otoritarianisme regim Arab, tetapi lebih dari itu merupakan "keterbelakangan" (takhalluf) dan "kebodohan" (jahl) dari masyarakat Arab itu sendiri. Secara lebih spesifik disimpulkan bahwa masyarakat Arab gagal memutuskan tendensi tradisional dan konservatif sehingga mencegah mereka melakukan internalisasi spirit modernitas dalam bentuk positif, humanistik, dan bahkan revolusioner (Sheehi, 2004: 3).

Intelektual Arab Marxis/Kiri mengadvokasikan modernisasi total sejalan dengan garis revolusi dan putus dari tradisi masa lalu. Mereka mengkritisi revolusi Arab kontemporer sebagai tidak sepenuhnya dan hanya parsial saja (Dessouki, 1973: 190). Intelektual representatif dari kelompok Marxis/Kiri ini adalah Hussain Muruwwa, Mahdi 'Amil, Fawwaz Tarabulsi, dan Karim Muruwwa dari Libanon; Yassin al-Hafiz, Elias Murqus, Sadek Jalal al-'Azm, Tayyib Tizini, dan Adonis dari Syria; Hisham Sharabi dari Palestina; Samir Amin, Luthfi al-Khuli, Ibrahim Sabri 'Abdallah, Fu' ad Mursi, Rif' at al-Sa'id, Ahmad Sadiq Sa'd, Ghali Syukri, dari Mesir; Abdallah Laroui dari Maroko; Talal Asad dari Saudi Arabia; dan Hadi alUlwi dari Iraq (Abu-Rabi', 2004: 87).

Dalam sebuah interview pada tahun 1997, Sadek Jalal al-'Azm, seorang filsuf dari Damaskus dan mendapat pendidikan dari Yale University mengatakan bahwa akibat dari kekalahan 1967 sebagai berikut:

"Naturally, the defeat of June 1967 interrupted all plans and revealed the fragility of the modern
Arab intellectual renaissance on which the Arab liberation movement based its hopes. Most of these hopes revolved around the concept of the inspired leader and when the leader fell every thing crashed with him, leaving nothing behind but emptiness, loss, and confusion. I would not be exaggerating when I say that the defeat hit us like a lightening bolt."

Lebih lanjut ia mengatakan:

"The 1967 defeat was an exceptional event in every sense of the word, a terrifying explosion which destroyed the foundations of the Arab liberation movement."

Gerakan pembebasan tersebut khususnya dalam tren sosialisnya di bawah kepemimpinan Nasser. Menurut al-Azm, revolusi 1952 yang dipimpin Nasser tersebut memang telah menjalankan transformasi ekonomi dan politik dengan menggulingkan pemimpin monarki dan memperluas kekuasaan dengan cara redistribusi tanah dan menghapus sistem feodal. Akan tetapi, upaya tersebut tidak menyentuh "super struktur" masyarakat Arab yaitu system of thought, value, dan belief. Menurutnya lagi, kekalahan 1967 sebagai akibat dari masih menguatnya pemikiran konservatisme (Kassab, 2010: 74).

Kekurangan yang lain dalam pandangan al-'Azm adalah karena masyarakat Arabgagal memproklamirkan sifat ilmiah dan sekuler dari ideologi sosialisme. Pada kenyataannya, revolusi Arab belum menangani problem fundamental masyarakat semisal masa depan pertanian, kepemilikan tanah, sekularisasi, dan relasi kelas. Konsekuensi dari ketidak jelasan ideologi ini adalah lahirnya sikap wasathiyyah (tengah-tengah, middle-of-theroadism), sebagai karakter utama revolusi Arab selama ini (Dessouki, 1973: 190). Sekularisme dalam pandangan al-Azm menjadi sebuah keharusan agar masyarakat Arab mampu maju dan bersaing dengan negara-negara maju lainnya.

Bagi al-Azm (1998: 67-76) sekularisme atau yang ia sebut dengan civil government (hukumah madaniyyah) merupakan prekondisi bagi demokrasi. Sekularisme adalah 
sikap netral yang wajib ditampilkan oleh negara terkait agama, sekte, denominasi, dan kategori-kategori etnis yang seringkali menjadi persoalan di masyarakat. Lebih jauh al-Azm menegaskan bahwa sekularisme adalah pilihan sejarah. Islam dapat menerima sekularisme sepanjang kita mampu membedakan antara "doctrinaire no" (allā assuratiyyah) dan "historic yes" (an-na'am at-tārikhiyyah). Doctrinaire no, memandang bahwa sistem poilitik yang pernah dijalankan (kekaisaran) dipandangan tidak sejalan dengan Islam, meskipun dalam sejarahnya telah terbukti memajukan Islam. Sedangkan historic yes, memandang bahwa Islam dalam perjalanan sejarahnya selalu mampu beradaptasi dengan berbagai ideologi yang pernah ada.

Dengan demikian, sekularisme sebagai sebuah "historic yes" pada zaman modern dapat diterima Islam sebagaimana Islam pernah berhasil melalui serangkaian sejarah panjang dalam menafsirkan dan mendefinisikan diri. Islam dipandang dari sudut doktiner, maka hanya akan kompatibel dengan dirinya sendiri apabila Islam dipandang sebagai fakta sejarah dengan telah terbukti mampu berkompetisi dalam panggung politik, sosial, dan organisasi ekonomi.

Meskipun demikian, al-Azm tidak setuju apabila pemikiran agama menjadi fondasi bagi perubahan. Menurutnya, pemikiran agama hanyalah kesadaran palsu dan tidak dapat sejalan dengan pemikiran ilmiah autentik. Pemikiran agama ini sangat berbahaya karena terkadang digunakan untuk mendukung tatanan sosial yang ada dan mereka yang berada dibelakangnya, serta mencegah terjadinya gerakan pembebasan sosial dan politik (Hourani, 1992). Termasuk dalam sikap ini, ia mengkritik Adonis atau Ali Ahmad Said (lahir 1930), sebagai intelektual Marxis lainnya yang cenderung bersimpati dan mengagumi Revolusi Islam Iran 1979. Hal ini menurut penulis dapat dipahami karena Adonis lahir dan besar dalam tradisi Syi'ah.

\section{Kritisisme Liberal}

Schumman (2008: 404) mewanti-wanti bahwa meskipun intelektual Arab liberal tidak banyak dibicarakan, ini bukan berarti "the absence of "voices" does not prove the sufficiently the nonexistence of liberal ideas in the Arab world," karena gaung mereka memang tidak selantang kelompok nasionalis atau fundamentalis. Sejakakhir abad ke-19Masehi, pemikiran liberal seringkali dianggap sebagai adopsi dari gagasan-gagasan Barat dan karenanya dianggap "inauthentic." Bahkan, intelektual liberal seringkali dituduh sebagai agen Barat. Faktor lain yang membuat pemikiran liberal ini tenggelam di dunia Arab karena kecenderungan mereka yang berani mengkritisi pemerintahan sehingga sering tersisihkan (2008: 404-405).

Intelektual Arab-Muslim liberal dapat dilacak pada era Kebangkitan Arab Pertama seperti Taha Hussein, Ali Abd al-Raziq, Salim al-Bustani, dan Khalid Muhammad Khalid (Abu-Rabi, 2004: 74). Pada konteks kontemporer terdapat sederetan tokoh seperti Hisham Sharabi, Anwar Abd alMalik, Jalal Amin, Samir Amin, dan Abd alKabir al-Khatibi, dan Hasan Hanafi (Boullata, 2001: 122).

Menurut kelompok liberal, kekalahan Arab1967 dan kemenangan bangsaZionis Israel terletak pada superioritas sistem sosial mereka yang didasarkan pada nilai-nilai kehidupan Barat modern, sementara bangsa Arab masih jauh dari hal demikian. Para penulis liberal lainnya seperti Zureiq, Adonis, Abdullah Abd al-Dayim, dan Munir al-Ba'labaki menekankan pentingnya perencanaan dan sekularisasi pendidikan, sains, dan teknologi sebagai solusi keterpurukan bangsa Arab (Dessouki, 1973: 189).

Intelektual Arab lainnya Farag Fauda (1945-1992 Masehi), penulis liberal Mesir terkemuka dan mengabdikan seluruh aktivitasnya dalam menentang Islam fundamentalis. Pemikiran Fauda didasarkan pada interpretasi rasional terhadap Islam yang kemudian menghantarkannya pada dua tujuan: menolak tuntutan penerapan syari'ah yang dalam pandangannya akan 
merusak kesatuan nasional antara penganut Kristen Koptik Mesir dengan umat Muslim; dan melegitimasi eksistensi civil government yang didasarkan pada pemisahan agama dan negara serta menjamin hak-hak universal manusia (Hatina, 2007: 9).

Farag Fauda seperti dikutip Hatina termasuk intelektual Arab liberal yang sangat meratapi difitisme 1967:

"Time stood still for me... I felt worthless, foolish and helpless. A strong desire to die or to hide took hold of me. Everything before me became small and pitiful. It seemed to me that Egypt had died and was finished, and I saw no alternative but to bury myself in history books." Hatina (2007: 48),

Dalam merespon peristiwa di atas, Fauda menyayangkan akan menguatnya respon dari kalangan Islamis atau fundamentalis. Dalam pandangan Fauda, solusi kalangan Islamis tidak dapat menyelesaikan persoalan yang dihadapi dunia Arab dan Muslim pada umumnya karena mereka hanya berfokus pada pemikiran agama saja bukan pada persoalan nasional. Kelompok fundamentalis juga seringkali terjebak pada retorika agama semata.

\section{Kritisisme Fundamentalis}

Penyebab utama dari an-Nakbah (kekalahan 1967) ini menurut kelompok fundamentalis karena memudarnya nilainilai Islam. Faktor keimanan sebagai penyebab utama kekalahan dan ideologi sekuler merupakan sebab kekalahan lain (Nagawasa, 1992: 66). Sikap frustasi kelompok fundamentalis ini seringkali diungkapkan dalam bentuk blame the others dengan menyalahkan kelompok atau ideologi lain sebagai biang kerok kekalahan bangsa Arab dari Zionisme Israel (Lewis, 2002).

Bagi kalangan fundamentalis, sejak bangsa Arab berpaling dari Islam dan mulai menerapkan nasionalisme dan sosialisme yang nota bene merupakan impor dari Barat dan sekaligus asing bagi Islam juga asing bagi mentalitas Muslim itu sendiri, maka keduanya telah membinasakan bangsa
Arab-Muslim. Nasionalisme umpamanya telah menghancurkan Turki Ustmani dan melemahnya Islam. Begitu pula hal yang sama terjadi pada ideologi sosialisme, yang telah menghantarkan pada kerusakan, kemiskinan, hilangnya kebebasan, dan akhirnya kekalahan (Dessouki, 1973: 189).

Penganut fundamentalis juga memandang an-Nakbah atau difitisme $1967 \mathrm{M}$ sebagai simbol kekalahan sosialisme Arab. Singkatnya, an-Nakbah bukanlah kekalahan negara atau tentara Arab melainkan gejala dari gagalnya trend ideology-ideologi Barat seperti sekularisme, liberalisme, sosialisme, dan nasionalisme karena semuanya bertolak belakang dengan prinsip-prinsip dasar Islam. Intelektual sekaligus tokoh fundamentalis post-1967 Masehi di antaranya Abd al-Qadir 'Awdah, Yusuf alQardawi, Muhammad al-Ghazali, Hassan al-Turabi, Rashid al-Ghannusyi, Sayyid Qutb, dan Muhammad Qutb, juga ada Omar bin 'Abd al-Rahman (Abu-Rabi', 2004: 70),. Mereka merepresentasikan tren kelompok fundamentalis kontemporer yang berpengaruh kuat terhadap lahirnya gerakan-gerakan fundamentalis modern di berbagai negara baik yang didominasi oleh kaum Muslim maupun tidak.

\section{Kritisisme Nasionalis}

Sejak kekalahan negara-negara Arab pada tahun 1967 dan meningkatnya kekayaan minyak yang sangat pesat secara tiba-tiba pada tahun 1970-an, situasi politik beralih total, yaitu penentangan yang kuat terhadap pan-Arabisme dan lebih memihak pada rezim negara nasional. Arus yang sangat kuat ini mengidentifikasi kepentingan "Arab" secara lebih partikular (Lapidus, 2007: 179). Maka difitisme 1967 telah melahirkan rasa nasionalisme yang lebih bersifat lokal, dan nasionalis model Nasseris juga Aflaq dengan sendirinya runtuh beserta pan-Arabismenya (Hatina, 2007: 8; Abu-Rabi', 2004: 79).

Pasca difitisme 1967 M, nasionalis Arab memang gagal untuk mewujudkan agenda besar mereka yaitu Arab unity. Begitu juga kelompok Islam fundamentalis Arab tidak 
mampu menggulingkan seorang regim dan tidak mampu mendirikan sebuah negara syari'ah-based. Meskipun demikian, nasionalisme Arab dan Islamisme masih merupakan ideologi dominan di Timur Tengah.

Nasionalisme dan Islamisme belum gagal, yang gagal adalah versi radikal. Kedua ideologi tersebut melewati periode radikalisasi dan berakhir sekitar dua atau tiga dekade yang lalu. Nasionalisme Arab radikal mengalami masa subur secara intelektual selama tahun 1940 dan 1950-an (dengan karya-karya monumental dari al-Hursi, 'Aflaq, al-Arsuzi, dan Zurayk). Hal yang sama dialami oleh ideologi Islam selama 1960 dan 1970-an (karya-karya Abu al-'Ala al-Mawdudi, Sayyid Qutb, Baqir Sadr, dan Ruhulloh Kehomeini) (Schumann, 2008: 409).

\section{SIMPULAN}

Dari analisis terhadap respon-respon yang berbeda atas an-nakbah atau difitisme 1967, maka menurut Dessouki (1973: 191) terdapat hipotesis bahwa dengan mendalamnya situasi krisis di dunia Arab, sebuah polarisasi mungkin saja terjadi antara pemikiran Islam dan pemikiran revolusioner sementara tren liberal-sekular dan middle-ofthe-roadism (seperti sikap mayoritas ulama AlAzhar yang cenderung cari selamat) menjadi semakin terpinggirkan. Faktor utama yang menyebabkan terjadinya polarisasi karena gagalnya pemikiran Arab modern untuk menghasilkan sintesis bermakna antara Islam sebagai agama massa dengan sumber utamanya sistem nilai (tradisi Islam klasik atau turāst) dengan modernitas yang termanifestasi dalam kebudayaan dan kultur modern Barat. Upaya Muhammad Abduh berakhir dengan ortodoksi dan pemikiran sosial-politik konservatif, yakni Salafisme dan kemudian Ikhwanul Muslimin. Di satu sisi tren sekularis 'westernis' terlalu abstrak dan general.

Pendapat sebaliknya disampaikan oleh Browers (2009: 19), menurutnya ideologi sekuler dengan corakkritisisme dan cenderung kiri justeru muncul dan cukup menguat pasca difitisme 1967 di samping semakin menguatnya gerakan fundamentalisme Islam. Akan tetapi, peristiwa the Arab Spring yang terjadi akhir-akhir ini lebih memihak pada tesis Laroui (1976), yaitu ideologi Islam fundamentalis akan semakin menguat dan ini terbukti di Tunisia dan khususnya Mesir dengan menangnya gerakan Ikhwanul Muslimin (IM) sebagai pemegang kekuasaan. IM sejak berdirinya pada 1928 Masehi baru pertama kali dalam sejarah panjangnya mampu mendirikan sebuah partai yaitu Hizbul Hurriyyah wal 'Adālah (Partai Pembebasan dan Keadilan) pada tahun 2011 dan menghantarkan Muhammad Mursi sebagai presiden Mesir sipil pertama dari kalangan IM sendiri. Tidak hanya itu saja, gerakan-gerakan Islam lain seperti Salafiyah pun telah berhasil mendirikan partai Hizbun$N \bar{u} r$ (2011). Sedangkan gerakan militan seperti Jama'ah Islamiyyah semakin gencar melakukan berbagai protes dan tuntutan penerapan syari'at Islam. Sementara itu, suara-suara kritis intelektual sekuler, liberal atau Marxis hanya mampu menghiasi berbagai media independen Mesir semisal al-masry al-youm tanpa dibarengi dukungan massa yang kuat.

Singkatnya, gerakan fundamentalisme Islam yang diwakili oleh IM sedang dipertaruhkan reputasi politiknya di hadapan masyarakat Mesir khususnya dan dunia Muslimpadaumumnya. Pascadikeluarkannya draft konstitusi baru oleh presiden Mursi yang telah menuai badai protes utamanya dari kalangan sekuler meskipun pada akhirnya draft tersebut mendapat dukungan cukup signifikan yaitu 63.8\%, masyarakat dunia sedang menantikan apakah IM dengan partai Hizbul Hurriyyah wal 'Adālah-nya dan Mursi sebagai presidennya akan segera melahirkan kebijakan-kebijakan revolusioner seperti yang pernah dilakukan Nasser pasca-revolusi Juli 1952 telah berhasil membawa perubahan besar pada waktu itu. Dunia Muslim sedang menantikan gebarakkan tersebut dan ini akhirnya dapat menjadi renungan bagi intelektual Muslim bahwa ideologi Islam barangkali masih dapat menjadi ideologi 
penyelamat atas kemunduran yang sedang terjadi sehingga ideologi-ideologi sekuler semakin terbukti tidak dapat diterapkan. Ataukah sebaliknya, andaikan IM sebagai representasi ideologi Islam menemui kegagalan haruskan ideologi-ideologi sekuler semisal Marxisme dan Liberalisme dapat dipertimbangkan kembali sebagai ideologi alternatif setelah dimodifikasi dan melalui proses kreativitas intelektual terlebih dahulu seperti yang pernah dilakukan Nasser dengan Pan-Arabisme-nya.

\section{DAFTAR PUSTAKA}

Abu-Rabi, I. M., 2006, Contemporary Islamic Intellectual History: A Theoretical Perspective, Singapore: Majelis Agama Islam Singapura.

, 2004, Contemporary Arab Thought: Studies in Post-1967 Arab Intellectual History, London: Pluto Press.

Ajami, F, 1992, The Arab Predicament: Arab Political Thought and Practice since 1967, New York: Cambridge University Press.

Al-Azm, S. J. \& Fakhr, A., 1998, “Trends in Arab Thought: An Interview with Sadek Jalal al-Azm." Journal of Palestine Studies, 27, 68-80.

Al-Jabiri, M. A., 1990, Isyakāliyāt al-Fikr al'Arabì al-Mu'āshir, Beirut: Markaz Dirāsāt al-Wihdah al-'Arabiyyah.

Barakat, H., 2012, Dunia Arab: Masyarakat, Budaya dan Negara, Bandung: Nusa Media.

Boullata, I. J., 2001, Dekonstruksi Tradisi: Gelegar Pemikiran Arab Islam, Yogyakarta: LKiS.

, 1988, Challenges to Arab Cultural Authenticity, The Next Arab Decade: Alternative Futures, Boulder: Westview Press.

Browers, M, 2009, Political Ideology in the Arab World: Accommodation and Transformation, Cambridge:
Cambridge University Press.

Dessouki, A. E. H., 1973, “Arab Intellectuals and Al-Nakba: The Search for Fundamentalism," Middle Eastern Studies, 9, 187-195.

Esposito, J. L. \& Sou'yb, H. M. J., 1990, Islam dan Politik. Jakarta: Bulan Bintang.

Hatina, M., 2007, Identity Politics in the Middle East: Liberal Thought and Islamic Challenge in Egypt, London: IB Tauris \& Company.

Hourani, A.,1992, A History of the Arab Peoples, New York: Harvard University Press.

1983, Arabic Thought in the Liberal Age, 1798-1939, New York: Cambridge University Press.

Kassab, E. S., 2010, Contemporary Arab Thought: Cultural Critique in Comparative Perspective, New York: Columbia University Press.

Kurzman, C, (ed.) 2003, Wacana Islam Liberal: Pemikiran Islam Kontemporer Tentang Isu-Isu Global, Jakarta: Paramadina.

Lapidus, I. M., 2007, A History of Islamic Societies, New York: Cambridge University Press.

Laroui, Abdallah., 1976, The Crisis of the Arab Intellectual: Traditionalism or Historicism? California: University of California Press.

Lewis, B., 2002, What Went Wrong?: The Clash between Islam and Modernity in The Middle East, New York: Harper Perennial.

Nagawasa, E., 1992, “An Introductory Note on Contemporary Arabic Thought." Mediterranean World, 13, 65-71.

Schumann, C, 2008, "The "failure" of Radical Nationalism and The "silence" of Liberal Thought in The Arab World." Comparative Studies of South Asia, Africa and the Middle East, 28, 404-415.

Sharabi, H. B., 1992, Neopatriarchy: A Theory 
of Distorted Change in Arab Society, New York: Oxford University Press.

,1966, "The Burden of the Intellectuals of the "Liberal Age"," Middle East Journal, 20, 227-232.

Sheehi, S., 2004, Foundations of Modern Arab Identity, Gainesville: University Press of Florida.
Talhami, G, 1997, “An Interview with Sadik Al-Azm," Arab Studies Quarterly (asq), 19. 